\title{
Bioimmunological responses to Schistosoma mansoni and Fasciola gigantica worm homogenates either with or without saponin
}

\author{
Amany Sayed Maghraby², Manal Abdel-Aziz Hamed ${ }^{1}$, Sanaa Ahmed Ali $^{1}$ \\ ${ }^{1}$ Therapeutic Chemistry Department, National Research Center, Dokki, Cairo, Egypt \\ ${ }^{2}$ Therapeutic Chemistry Department, Laboratory of Immunology and Infectious Diseases, Center of Excellence for Advanced \\ Sciences, National Research Center, Dokki, Cairo, Egypt
}

\begin{abstract}
Background: In this study, we evaluated the biochemical, immunological, histopathological and antischistosomal activities of Schistosoma mansoni or Fasciola gigantica worm homogenates mixed either with or without saponin that was extracted from Atriplex nummularia. Methodology: The immunization schedule was based on subcutaneous administration of two doses $(50 \mu \mathrm{g} / 100 \mu \mathrm{l}$ PBS) of each homogenate with time intervals of 15 days. After 15 days of the last homogenate inoculation, all mice were challenged with 100 Schistosoma mansoni cercariae and sacrificed after two months. Free radical scavengers and liver function enzymes were determined in mice liver. Worm counting and the histopathological picture of the liver were also done.

Results: Immunization with Schistosoma or Fasciola worm homogenates, mixed either with or without saponin, recorded an amelioration of the free radical scavenger levels, liver function enzymes and reduction in worm burden, as well as improvement of the histological feature of the liver, the number and size of granuloma, evidence of increased immune reaction manifested by a lymphocytic cuff surrounding the granuloma, diminution of its fibrotic and collagen content, and destruction of Schistosoma ova.

Conclusion: Fasciola or Schistosoma worm antigens mixed with or without saponin succeeded to eliminate the product of oxidative stress and assistance in immune-mediated destruction of eggs that ameliorate the histopathological picture of the liver cells and preserve its function.
\end{abstract}

Key words: Schistosoma mansoni; Fasciola gigantic; saponin; immunoglobulins; free radical scavengers; liver histology

J Infect Dev Ctries 2010; 4(5):334-344.

(Received 27 August 2009 - Accepted 13 January 2010)

Copyright $\left({ }^{\circ} 2010\right.$ Maghraby et al. This is an open-access article distributed under the Creative Commons Attribution License, which permits unrestricted use, distribution, and reproduction in any medium, provided the original work is properly cited.

\section{Introduction}

Vaccination is one of the new trends to control schistosomiasis. Vaccines that can reduce schistosomiasis morbidity and mortality by lowering the intensity of infection or by modifying the immune response to parasite-derived antigen should be adopted for use, even if they are not effective in complete elimination of the parasites [1-2]. A common antigen or antigenic determinant in the family of the pathogenic trematodes of humans appears to be at least partially responsible in the development of acquired resistance to challenge infection with homologous or closely related genera, as fascioliasis [3]. Fasciola can be used as a source of antigen because the fascioliasis worm has common or cross-reacting antigens with schistosomes, is associated with high eosinophil levels, and is capable of inducing specific immunological defense against schistosomiasis [4]. Moreover, the Fasciola worm provides a good source of antigen because of its large size and because it is easy and safe to maintain experimentally.

Saponins are a heterogeneous group of sterol and triterpene glycosides, which have been isolated from a broad range of plants [5]. Saponins exhibit cell membrane-permeabilizing properties and thus have been investigated for their therapeutic potential [6]. Saponin isolated from Schefflera leucantha Viguier leaves showed no acute toxicity up to $5,000 \mathrm{mg} / \mathrm{kg}$ where no mortality or significant changes in the general behavior and gross appearance of the internal organs of rats were observed [7]. A steroidal saponin of yam (Dioscorea spp) was reported to have a hypocholesterolemic effect by both improving the lipid profile and modulating oxidative stress [8]. In in vitro and in vivo mice models, saponin from sea cucumber exhibits anti-angiogenic and anti-tumor activities [9]. Notably, saponins can also activate the mammalian immune system, which has led to significant interest in their potential as a vaccine 
adjuvant [10]. Adjuvants can be classified depending on whether or not they have a direct immunostimulatory effect on immune antigen presenting cells or function as an antigen delivery system. De Sousa et al. [11] mentioned that saponins have the property of direct immunostimulatory effect. Saponin-type adjuvants have been shown to influence the immune system in several ways: they can stimulate cytotoxic CD8+ lymphocyte proliferation, enhance cytokine production, and up-regulate the adaptive humoral response [12].

In this study, we evaluate the use of Schistosoma mansoni or Fasciola gigantica worm homogenates either alone or followed by immunization with saponin to induce protection against $S$. mansoni infection in mice. This evaluation was mediated by immunobiochemical, parasitological, and histopathological determinations. The levels of IgM and $\mathrm{IgG}$ in mice sera before and after immunization were detected. Free radical scavengers (lipid peroxide, glutathione [GSH], vitamin $\mathrm{C}$, vitamin $\mathrm{E}$, catalase, superoxide dismutase [SOD]) as well as liver function enzymes (aspartate aminotransferase [AST], alanine aminotransferase [ALT] and alkaline phosphatase [ALP]) were carried out. The total eradication of worms and the histopathological picture of the liver were done to confirm our results.

\section{Materials and methods}

Animals

Female Swiss albino mice CDI strain weighting $18-22 \mathrm{~g}$ were obtained from the National Research Centre, Cairo, Egypt, and maintained on a stock commercial pellet diet (El-Kahira Company for Oil and Soap) and provided water ad-libitum.

\section{Plant material}

Samples from the whole plant of Atriplex nummularia were collected from the Marsa Matroh Desert, Cairo, Egypt. The plant is a shrug or herb belonging to the family Chenopodaceae, and it can be up to $5 \mathrm{~cm}$ long with broad and frequently sharply dentate. Fruits are perianth rounded cordate, papery with eroded-dentate margine and a hardened base.

Isolation of saponins from the plant was by the method of Maghraby et al. [13], where $80 \%$ of ethanolic extract was carried out. The extract was concentrated under reduced pressure, macerated with water and partitioned successively using ethyl acetate and $\mathrm{n}-\mathrm{BuOh}$. The $\mathrm{n}-\mathrm{BuOH}$ soluble fraction and the aqueous part afford the major saponin fractions. However, less polar saponin constituents may be present in the ethyl acetate part. The crude saponin fractions were applied separately to columns of Diaion HP-20 which were washed with water-ethanol in various ratios $(0,20,30,4,60,80$ and $100 \%$ $\mathrm{EtOH})$. The fractions found to have the same pattern on thin layer chromatography (TLC) are mixed together and further purified by silica gel column choromotography, ODS medium pressure LC and finally by HPLC on ODS column using ethanolwater as eluent to achieve high purity.

\section{Antigen preparation}

All antigens used for ELISA technique (cercariae, worm and egg antigens of $S$. mansoni) were obtained from Theodore Bilharz Research Institute, Giza, Egypt. Fasciola gigantica worm homogenate was prepared and injected according to Maghraby et al. [14]. The protein content of each antigen was determined by the method of Bradford [15]. Each animal received $50 \mu \mathrm{g}$ protein/mouse at 0 and 15 days. The total antigen dose was $100 \mu \mathrm{g}$ protein/mouse.

\section{Experimental design and immunizations}

Sixty female Swiss albino mice were divided into twelve groups (5mice/group). Group 1 served as the normal control group, subcutaneously injected with $100 \mu \mathrm{l}$ of phosphate buffer saline (PBS). At days 0 and 15, groups 2 to 6 subcutaneously received $50 \mu \mathrm{g}$ protein $/ 100 \mu \mathrm{l}$ PBS of Schistosoma worm homogenate, $50 \mu \mathrm{g} / 100 \mu \mathrm{l}$ PBS of saponin extracted from Atriplex nummularia, Schistosoma worm homogenate mixed with saponin $(50 \mu \mathrm{g} / 100 \mu \mathrm{l}$ PBS each), Fasciola worm homogenate, and Fasciola worm homogenate mixed with saponin, respectively. Group 7 served as infected mice with 100 S. mansoni cercariae using the tail immersion technique [16]. Following the second immunization of each antigen, groups 8 to 12 were left free for 15 days then challenged by $100 \mathrm{~S}$. mansoni cercariae and sacrificed after two months of infection.

\section{Enzyme linked Immunosorbent Assay (ELISA)}

The assay was performed according to the Hillyer et al. [17]. This assay was used to determine the levels of $\operatorname{IgG}$ and $\operatorname{IgM}$ in the sera of the experimental groups. Plates were coated with different types of antigens: Cercarial antigen preparation (CAP), soluble worm antigen preparation (SWAP) and egg antigens (SEA). Plates were incubated at room temperature overnight. They were washed using PBS-0.05\%T20 and blocked for sites 
free of antigen using blocking buffer (1\%BSA -PBS$0.05 \% \mathrm{~T} 20)$, then sera at a dilution of 1:100 in PBS were added and incubated at $37^{\circ} \mathrm{C}$ for 2 hours. Antimouse IgG and IgM peroxidase conjugates were added at a dilution of 1:5,000 in 1\% BSA -PBS 0.05 $\%$ T-20 and incubated for an hour at $37^{\circ} \mathrm{C}$. Orthophenylene diamin dihydrochloride (OPD) was used as substrate. The reaction was read at $490 \mathrm{~nm}$ using ELISA Reader.

\section{Biochemical determinations}

Preparation of tissue homogenate: Liver tissue was homogenized in double distilled water and $20 \%$ of liver homogenate was prepared for estimation of lipid peroxide, glutathione, vitamin $\mathrm{C}$ and $\mathrm{E}$, catalase and superoxide dismutase. Further dilution of liver homogenate to $10 \%$ was prepared for determination of AST, ALT and ALP. For the assays of different parameters, protein was estimated by the method of Bradford [15], where bovine serum albumin was used as a standard protein and the colour developed was read colourimetrically at $595 \mathrm{~nm}$. Lipid peroxide was determined as malondialdehyde. Its concentration was calculated using the extinction coefficient value $1.56<105 \mathrm{M}-1 \mathrm{~cm}-1$ and read at $535 \mathrm{~nm}$ by the method of Buege and Aust. [18] Glutathione was estimated, using pithiobis-2-nitrobenzoic acid (DTNB) in PBS. The reaction colour was read at $412 \mathrm{~nm}$. The method adapted by Jogata and Dani [19] was used for estimation of vitamin $\mathrm{C}$ using Folin reagent and the developed colour was read at $760 \mathrm{~nm}$. Vitamin E was measured by the colourimetric assay of Angustin et al. [20]. The method is based on the oxidation of xylene-extracted tocopherols of the liver homogenate by ferric chloride and the pink complex of ferrous ions, bathophenanthoroline, was measured at $536 \mathrm{~nm}$. Catalase activity was assayed spectrophotometrically following decrease in absorbance at $230 \mathrm{~nm}$ using the molar extinction coefficient of hydrogen peroxide (62.4) according to Nelson and Kiesow [21]. Superoxide dismutase was estimated by the method of Nishikimi et al. [22]. The method depends on following increase in absorbance at $560 \mathrm{~nm}$ using molar extinction coefficient of NADH $(6.22 \times 103)$.

Alanine and aspartate aminotransferases: AST and ALT were measured by the method of Reitman and Frankel [23]. The colorimetric determination depends on determining amounts of oxaloacetate and pyruvate formed from the 2, 4-dinitrophenyl hydrazine of oxaloacetate and pyruvate; the developed color was read at $520 \mathrm{~nm}$. Alkaline phosphatase was estimated by the method of Kind and King [24]. The values were represented as liberated phenol at $510 \mathrm{~nm}$.

\section{Parasitological studies}

Worms were recovered by liver perfusion as described by Smithers and Terry [25]. The percent of reduction in worm burden after challenge was calculated by the method of Tendler et al. [26] as follows:

$$
\mathrm{P}=\mathrm{C}-\mathrm{V} / \mathrm{C} \times 100
$$

Where, $\mathrm{P}=$ protection $(\%) ; \mathrm{C}=$ mean number of parasite recovered from infected animals; and $\mathrm{V}=$ mean number of parasite recovered from vaccinated animals.

The relative sex ratio (RSR) was calculated by the method of Fallon et al. [27] according to the formula:

RSR $=$ The ratio of untreated groups was standardized as 1 .

\section{Histopathological studies}

Slices of liver tissue of all animals were collected and fixed in $10 \%$ buffered formalin solution for histopathological studies. Paraffin embedded sections ( $5 \mu \mathrm{m}$ thick) were taken after fixation and slides were stained using haemoatoxylin and eosin ( $\mathrm{H}$ and $\mathrm{E})$ by the method of Hirsch et al. [28].

\section{Statistical analysis}

Data in the present study has been expressed as mean $\pm \mathrm{SD}$ of eight mice in each group. The statistically significant difference between the control and other groups was determined by using the independent t-test [29].

\section{Results}

Table 1 shows IgM and IgG levels in mice sera immunized with Schistosoma or Fasciola worm homogenates followed by immunization either with or without saponin against CAP, SWAP or SEA using the ELISA technique. There was an elevation in the levels of IgM and IgG respectively in sera from mice immunized with SWAP or $F$. gigantica worm homogenates either alone or followed by immunization with saponin against CAP or SWAP or SEA. Contrarily, the IgM level after immunization with $F$. gigantica worm homogenates either alone or followed by immunization with saponin against CAP was not increased as compared with unimmunized mice. 
Table 1. Detection of IgM and IgG levels in mice sera immunized with S. mansoni or F. gigantica worm homogenates mixed with or without saponin.

\begin{tabular}{|c|c|c|c|c|c|c|}
\hline \multirow{2}{*}{ Groups } & \multicolumn{2}{|c|}{ CAP } & \multicolumn{2}{|c|}{ SWAP } & \multicolumn{2}{|c|}{ SEA } \\
\hline & IgM & IgG & IgM & IgG & IgM & IgG \\
\hline SWAP & $\begin{array}{c}0.76 \pm 0.19 \\
+(7.6 \text { folds })\end{array}$ & $\begin{array}{c}0.29 \pm 0.05 \\
+(3.6 \text { folds })\end{array}$ & $\begin{array}{c}0.24 \pm 0.04 \\
+(8.0 \text { folds })\end{array}$ & $\begin{array}{c}0.32 \pm 0.02 \\
+(5.3 \text { folds })\end{array}$ & $\begin{array}{l}0.33 \pm 0.17+ \\
(16.5 \text { folds })\end{array}$ & $\begin{array}{r}0.34 \pm 0.16 \\
+(5.7 \text { folds })\end{array}$ \\
\hline $\begin{array}{l}\text { SWAP } \\
+ \text { SAP }\end{array}$ & $\begin{array}{c}0.65 \pm 0.3 \\
+(6.5 \text { folds })\end{array}$ & $\begin{array}{c}0.4 \pm 0.07 \\
+(5.0 \text { folds })\end{array}$ & $\begin{array}{c}0.43 \pm 0.02 \\
+(14.3 \text { folds })\end{array}$ & $\begin{array}{c}1.07 \pm 0.03 \\
+(17.8 \text { fold })\end{array}$ & $\begin{array}{l}0.44 \pm 0.13 \\
+(22 \text { folds })\end{array}$ & $\begin{array}{c}0.68 \pm 0.06 \\
+(11.3 \text { folds })\end{array}$ \\
\hline FW+SAP & $0.01 \pm 0.007$ & $\begin{array}{c}0.39 \pm 0.2 \\
+(4.9 \text { folds })\end{array}$ & $\begin{array}{c}0.1 \pm 0.008 \\
+(3.3 \text { folds })\end{array}$ & $\begin{array}{c}0.69 \pm 0.34 \\
+(11.5 \text { fold })\end{array}$ & $\begin{array}{l}0.29 \pm 0.007 \\
+(14.5 \text { fold })\end{array}$ & $\begin{array}{c}0.97 \pm 0.4 \\
+(16.2 \text { folds })\end{array}$ \\
\hline Saponin & $\begin{array}{c}0.28 \pm 0.11 \\
+(28 \text { folds })\end{array}$ & $\begin{array}{l}0.62 \pm 0.06 \\
+(15 \text { folds })\end{array}$ & $\begin{array}{c}0.145 \pm 0.035 \\
+(4.3 \text { folds })\end{array}$ & $\begin{array}{c}0.9 \pm 0.02 \\
+(15 \text { folds })\end{array}$ & $\begin{array}{l}0.26 \pm 0.08 \\
+(13 \text { folds })\end{array}$ & $\begin{array}{c}0.8 \pm 0.05 \\
+(13.3 \text { folds })\end{array}$ \\
\hline Cont. & $0.015 \pm 0.003$ & $0.08 \pm 0.02$ & $0.029 \pm 0.01$ & $0.06 \pm 0.04$ & $0.018 \pm 0.004$ & $0.06 \pm 0.01$ \\
\hline
\end{tabular}

The levels of IgM and IgG in mice sera immunized with Schistosoma mansoni and Fasciola gigantica worm homogenate mixed with or without saponin and normal control were expressed by mean optical density (OD) \pm standard deviation (SD) at $492 \mathrm{~nm}$; each value represents mean of 5 readings. The cut-off value between immunized and non immunized sera was the mean absorbance of control+3 SD. Samples with OD level < cut-off value were negative and samples with OD level > cut-off value were positive and calculated as folds value.

Table 2. Detection of IgM and IgG levels in mice sera immunized with S. mansoni or F. gigantica worm homogenates mixed with or without saponin post challenged.

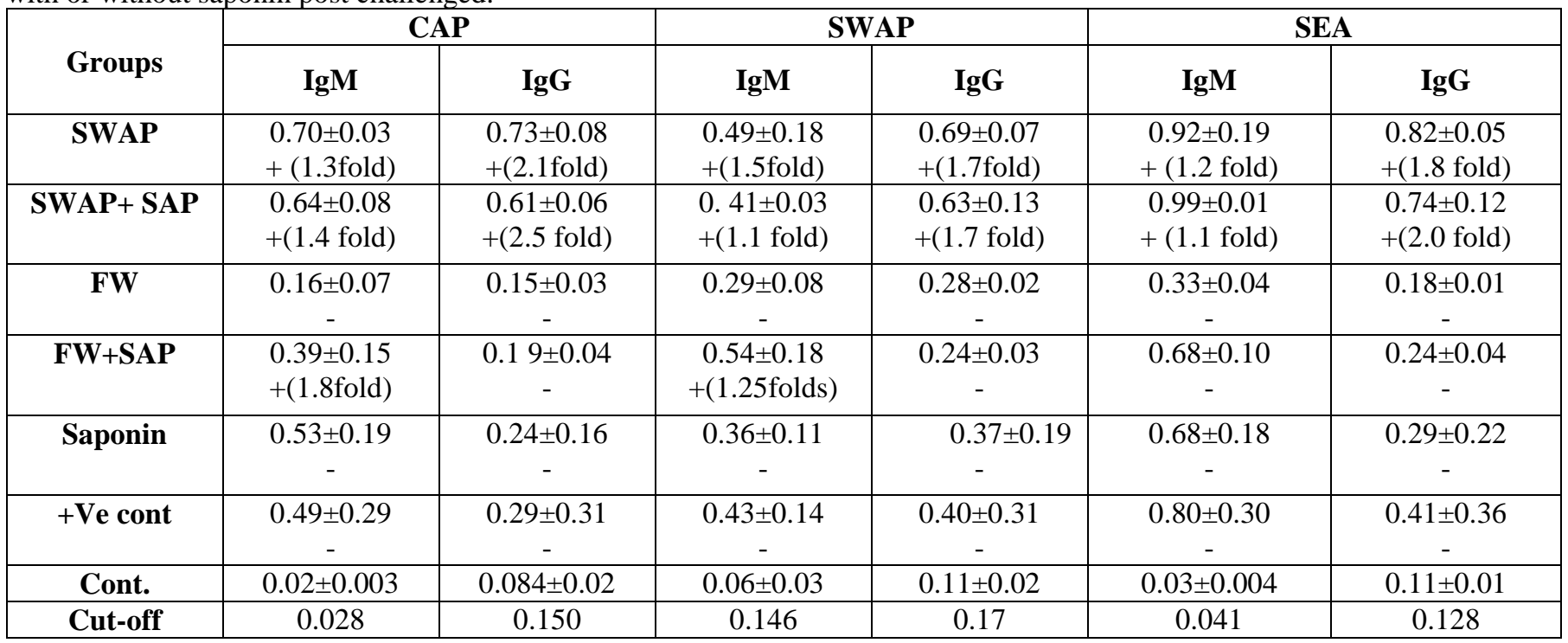

The levels of IgM and IgG in sera of immunized-challenged mice and positive infected control were expressed by mean optical density (OD) \pm standard deviation (SD) at $492 \mathrm{~nm}$, each value represents mean of 5

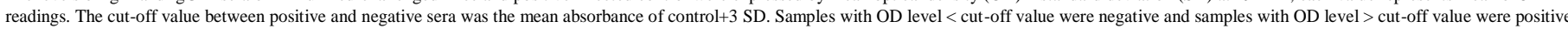

Table 2 shows $\operatorname{IgM}$ and $\operatorname{IgG}$ levels in sera of mice immunized with Schistosoma or Fasciola worm homogenates followed by immunization either with or without saponin and challenged with $100 \mathrm{~S}$. mansoni cercariaea against CAP using the ELISA technique. There was an elevation in IgM or IgG levels in immunized mice with SWAP followed by immunization with or without saponin against CAP or SWAP or SEA as compared with the infected group. The IgM or IgG levels were lower in sera from immunized mice with $F$. gigantica worm homogenates followed by immunization with or without saponin against CAP or SEA post challenge when compared with infected control sera.

IgM and IgG levels were lower in immunized mice with Fasciola worm homogenates against SWAP when compared with the unimmunized infected sera. While the IgM level was increased in sera from mice immunized with Fasciola worm homogenates after immunization with saponin, the $\mathrm{IgG}$ level was decreased when compared with unimmunized infected sera. 
Figure 1.
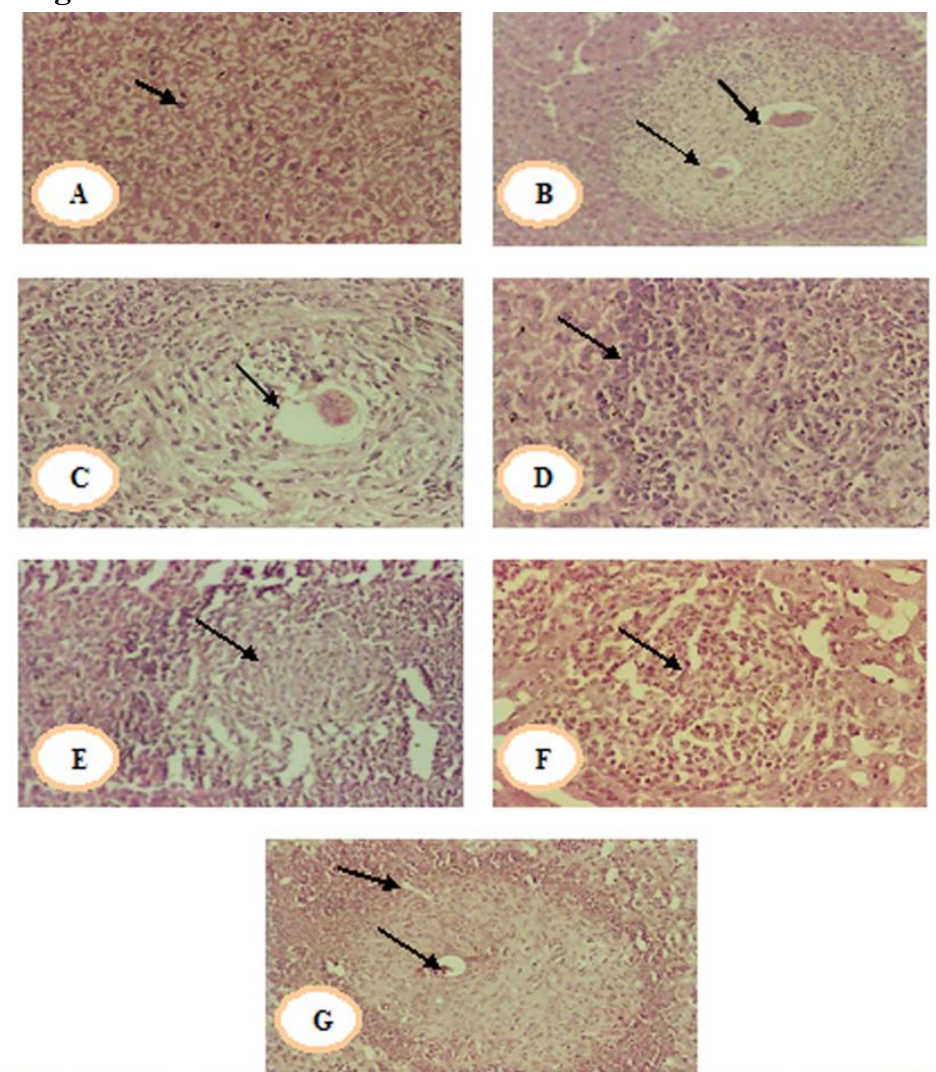

Fig. 1 - Sections through mice liver stained with hematoxylin and eosin (H \& E). [A] Control healthy liver (100 x). [B] Infected liver (S.mansoni) (200x). [C] Infected immunized mice with Fasciola worm \& saponin (200x). [D] Infected immunized mice with Fasciola worm (200x). [E] Infected immunized mice with saponin (100x). [F] Infected immunized mice with Schistos om a worm (200x). [G] Infected immunized mice with Schistosoma worm \& saponin (200x).

Table 3 shows insignificant change in the level of antioxidants and liver function enzymes after immunization of normal healthy mice with Fasciola or Schistosoma worm homogenates either alone or followed by immunization with saponin as well as saponin separately, indicating no side effects upon immunization with these antigens.

Table 4 shows the effect of immunization with saponin either alone or followed by immunization with Fasciola or Schistosoma worm antigens on the level of antioxoidants and liver function enzymes in infected mice. Infection with $S$. mansoni recorded significant increase in lipid peroxide, superoxide dismutase, and alkaline phosphatase activities. A significant decrease in vitamin $\mathrm{C}$, vitamin $\mathrm{E}$, catalase, glutathione, aspartate, and alanine aminotransferases levels were observed after infection. Immunizations with saponin, Fasciola or Schistosoma worm homogenates either alone or followed by immunization with saponin showed significant increase in lipid peroxide, superoxide dismutase and ALP, while vitamin C, vitamin $\mathrm{E}$, catalase, glutathione, AST and ALT activities still showed significant decrease as compared to the control group. With respect to both the control and infected groups, amelioration levels were recorded as a result of immunization with different antigens (Table 5).

Worm burdens, relative sex ratios, and reduction (\%) of worms in female mouse livers vaccinated with Fasciola and Schistosoma worm, saponin and its mixed antigens are shown in Table 6. Immunization with different antigens showed a reduction in the total of male and female worms. There was a higher mortality of female worms than male worms, as indicated by the higher relative sex ratio in immunized mice with all antigens used; also, the separate Fasciola worm antigen and saponin extract 
Table 3. Effect of immunization with Fasciola or Schistosoma worm homogenate, saponin and their mixed antigens on different antioxidant levels and liver function enzymes of healthy mice.

\begin{tabular}{|c|c|c|c|c|c|c|}
\hline Parameters & Control & Saponin & Fasciola worm & $\begin{array}{l}\text { Fasciola worm+ } \\
\text { saponin }\end{array}$ & $\begin{array}{l}\text { Schistosoma } \\
\text { worm }\end{array}$ & $\begin{array}{c}\text { Schistosoma worm } \\
\text { + saponin }\end{array}$ \\
\hline Lipid peroxide & $0.30 \pm 0.02$ & $\begin{array}{c}0.32 \pm \\
0.05(+6.66)\end{array}$ & $\begin{array}{c}0.33 \pm \\
0.05(+10.00)\end{array}$ & $\begin{array}{c}0.34 \pm \\
0.06(+13.33)\end{array}$ & $\begin{array}{c}0.35 \pm \\
0.06(+16.66)\end{array}$ & $0.34 \pm 0.05(+13.33)$ \\
\hline Glutathione & $124.5 \pm 2.11$ & $\begin{array}{c}122.62 \pm 3.12(- \\
1.51)\end{array}$ & $\begin{array}{c}121.8 \pm 3.27(- \\
2.13)\end{array}$ & $\begin{array}{c}120.52 \pm 3.25(- \\
3.19)\end{array}$ & $\begin{array}{c}121.73 \pm \\
2.54(-2.22)\end{array}$ & $121.41 \pm 3.77(-2.54)$ \\
\hline Vitamin C & $3.50 \pm 0.16$ & $3.33 \pm 0.22(-4.85)$ & $\begin{array}{l}3.28 \pm 0.27(- \\
6.28)\end{array}$ & $3.24 \pm 0.28(-7.42)$ & $\begin{array}{c}3.26 \pm 0.26(- \\
6.85)\end{array}$ & $3.22 \pm 0.29(-8.00)$ \\
\hline Vitamin E & $11.05 \pm 0.20$ & $\begin{array}{c}11.00 \pm 0.23(- \\
0.45)\end{array}$ & $\begin{array}{c}10.87 \pm 0.28(- \\
1.62)\end{array}$ & $10.86 \pm 1.25-2.08)$ & $\begin{array}{c}10.86 \pm 0.36(- \\
1.71)\end{array}$ & $10.80 \pm 0.32(-2.26)$ \\
\hline Catalase & $22.60 \pm 1.46$ & $\begin{array}{l}22.12 \pm 1.72(- \\
2.12)\end{array}$ & $\begin{array}{c}22.06 \pm 1.68(- \\
2.38)\end{array}$ & $21.86 \pm 1.25(-3.27)$ & $\begin{array}{c}21.89 \pm 2.24(- \\
3.14)\end{array}$ & $21.23 \pm 2.48(-6.06)$ \\
\hline $\begin{array}{c}\text { Superoxide } \\
\text { dismutase }\end{array}$ & $450.72 \pm 2.70$ & $\begin{array}{c}451.27 \pm \\
2.56(+0.12)\end{array}$ & $\begin{array}{c}452.27 \pm \\
2.5(+0.34)\end{array}$ & $\begin{array}{c}453.15 \pm \\
2.74(+0.53)\end{array}$ & $\begin{array}{c}452.51 \\
\pm 2.83(+0.39)\end{array}$ & $\begin{array}{c}453.66 \pm \\
2.71(+0.65)\end{array}$ \\
\hline $\begin{array}{c}\text { Aspartate } \\
\text { aminotransferase }\end{array}$ & $41.27 \pm 1.96$ & $\begin{array}{c}40.78 \pm 2.11(- \\
1.18)\end{array}$ & $\begin{array}{c}39.89 \pm 2.15(- \\
3.34)\end{array}$ & $39.60 \pm 2.23(-4.04)$ & $\begin{array}{c}38.86 \pm 2.21(- \\
5.83)\end{array}$ & $38.74 \pm 2.27(-6.13)$ \\
\hline $\begin{array}{c}\text { Alanine } \\
\text { aminotransferase }\end{array}$ & $20.66 \pm 1.36$ & $\begin{array}{c}20.23 \pm 1.56(- \\
2.08)\end{array}$ & $\begin{array}{c}19.97 \pm 1.83(- \\
3.33)\end{array}$ & $19.88 \pm 1.43(-3.77)$ & $\begin{array}{c}19.11 \pm 1.45(- \\
7.50)\end{array}$ & $18.95 \pm 1.62(-8.42)$ \\
\hline $\begin{array}{c}\text { Alkaline } \\
\text { phosphatase }\end{array}$ & $4.98 \pm 0.46$ & $\begin{array}{c}5.22 \pm \\
0.67(+4.81)\end{array}$ & $\begin{array}{c}5.42 \pm \\
0.78(+8.83)\end{array}$ & $\begin{array}{c}5.58 \pm \\
0.86(+12.04)\end{array}$ & $\begin{array}{c}5.46 \pm \\
0.53(+9.63)\end{array}$ & $5.66 \pm 0.67(+13.65)$ \\
\hline
\end{tabular}

recorded a higher mortality rate of female than male worms.

Microscopically, liver sections from the control group stained with Hematoxylin and Eosin showed normal parenchyma architecture as seen in Figure 1A. Normal mice vaccinated with different antigens showed more or less normal hepatic architectures; therefore, there was no need to display their figures. Severe damage of the liver structure was observed in infected animals with destruction of hepatic parenchyma due to multifocal acute reaction. The portal spaces were the main focus of severe alterations with chronic inflammatory reaction, bile duct hyperplasia, fibrosis, thickening, and thrombosis of portal vessels. The parasite remained encircled by fibrous tissue, and foreign body giant cells and intensive lymphoid reaction with follicular node formations were seen (Figure B).

All immunized animals developed hepatic and colonic granulomas that were considerably smaller than those formed in infected mice. The smaller hepatic granulomas in vaccinated mice were nevertheless effective in sequestering toxic egg products, as indicated by the lack of damage to the adjacent hepatocytes (Fig. C, D, E, F and G).

\section{Discussion}

Saponin used in the present study as a novel adjuvant dependent on the idea that vaccine formulations based on a novel adjuvant could improve the final outcome through selective manipulation of the immune response [30].

In trials of immunization against $S$. mansoni we have, on occasion, first observed a significant adjuvant effect, meaning that significant protection against parasite challenge was observed in groups given adjuvant alone, without any specific antigen, as compared with groups given neither antigen nor adjuvant. Haçariz et al. [12] found the same effect of saponin and attributed this phenomenon to saponin causing local exogenous tissue damage which leads to recognition of associated danger signals by the host's antigen presenting cells and thereby heightening immune responsiveness. This can drive the transition from T-helper 0 type (Th0) cells to Thelper 1 type (Th1) cells leading to IFN $\gamma$ secretion and triggering $\mathrm{IgG} 2$ production by $\mathrm{B}$ cells.

The second observation in the present study was the reduction of protection percent in mixed immunization. This was in accordance with 
Table 4. Effect of immunization with Fasciola or Schistosoma worm homogenate, saponin and their mixed antigens on different antioxidant levels and liver fuction enzymes in infected mice.

\begin{tabular}{|c|c|c|c|c|c|c|c|}
\hline Parameters & Control & Infected & Saponin & Fasciola worm & $\begin{array}{c}\text { Fasciola } \\
\text { worm+saponin }\end{array}$ & Schistosoma worma & $\begin{array}{c}\text { Schistosoma worm + } \\
\text { saponin }\end{array}$ \\
\hline Lipid peroxide & $0.30 \pm 0.02$ & $\begin{array}{c}0.52 \pm 0.03 \\
(+73)\end{array}$ & $0.4 \pm 0.01(+46.7)$ & $0.45 \pm 0.02(+50)$ & $0.48^{*} \pm 0.02(+60.00)$ & $0.48^{*} \pm 0.04(+60.00)$ & $0.50^{*} \pm 0.03(+66.00)$ \\
\hline Glutathione & $124.5 \pm 2.11$ & $\begin{array}{l}66.16^{*} \pm 2.58 \\
(-46.85)\end{array}$ & $109.44^{*} \pm 4.16(-12.09)$ & $97.21^{*} \pm 2.02(-1.91)$ & $87.34^{*} \pm 1.25(-29.84)$ & $90.32^{*} \pm 2.32(-27.45)$ & $80.21^{*} \pm 1.14(-35.57)$ \\
\hline Vitamin C & $3.50 \pm 0.16$ & $\begin{array}{c}1.58 * 0.03 \\
(-54.85)\end{array}$ & $2.86^{*} \pm 0.07(-18.28)$ & $2.59^{*} \pm 0.02(-26)$ & $2.09^{*} \pm 0.05(-40.28)$ & $2.28^{*} \pm 0.04(-34.85)$ & $1.98^{*} \pm 0.07(-43.42)$ \\
\hline Vitamin $E$ & $11.05 \pm 0.20$ & $\begin{array}{c}5.54^{*} \pm 0.24 \\
(-50.67)\end{array}$ & $9.03^{*} \pm 0.05(-18.23)$ & $8.28^{*} \pm 0.03(-25.06)$ & $7.73^{*} \pm 0.05(-30.05)$ & $8.34^{*} \pm 0.06(-24.52)$ & $7.11^{*} \pm 0.02(-35.65)$ \\
\hline Catalase & $22.60 \pm 1.46$ & $\begin{array}{c}15.19^{*} \pm 0.06 \\
(-32.78)\end{array}$ & $20.35^{*} \pm 0.07(-9.96)$ & $19.14^{*} \pm 0.09(-15.30)$ & $17.59^{*} \pm 0.24(-22.16)$ & $19.77^{*} \pm 0.06(-12.52)$ & $16.99^{*} \pm 0.26(-24.82)$ \\
\hline $\begin{array}{l}\text { Superoxide } \\
\text { dismutase }\end{array}$ & $450.72 \pm 2.70$ & $\begin{array}{c}603.45^{*} \pm 2.90 \\
(+33.88)\end{array}$ & $501.53^{*} \pm 2.73(+11.27)$ & $542.40^{*} \pm 2.69(+20.34)$ & $562.22^{*} \pm 2.70(+24.73)$ & $560.31^{*} \pm 2.27(+24.31)$ & $571.32^{*} \pm 2.17(+26.75)$ \\
\hline $\begin{array}{l}\text { Aspartate } \\
\text { aminotransferase }\end{array}$ & $41.27 \pm 1.96$ & $\begin{array}{c}22.11^{*} \pm 1.81 \\
(-46.42)\end{array}$ & $37.21^{*} \pm 1.61(-9.83)$ & $34.62^{*} \pm 1.71(-16.11)$ & $31.26^{*} \pm 1.86(-24.25)$ & $32.12^{*} \pm 1.64(-22.14)$ & $29.4^{*} \pm 21.53(-28.71)$ \\
\hline $\begin{array}{l}\text { Alanine } \\
\text { aminotransferase }\end{array}$ & $20.66 \pm 1.36$ & $\begin{array}{c}11.42 \pm 1.16 \\
(-44.72)\end{array}$ & $18.32^{*} \pm 1.24(-11.32)$ & $16.07^{*} \pm 1.32(-22.21)$ & $15.24^{*} \pm 1.11(-26.23)$ & $15.64^{*} \pm 1.41(-24.29)$ & $14.62^{*} \pm 1.21(-29.23)$ \\
\hline $\begin{array}{l}\text { Alkaline } \\
\text { phosphatase }\end{array}$ & $4.98 \pm 0.36$ & $\begin{array}{c}7.87^{*} \pm 0.42 \\
(+58.03)\end{array}$ & $5.78^{*} \pm 0.36(+16.06)$ & $6.11^{*} \pm 0.27(+22.69)$ & $6.23^{*} \pm 0.21(+25.10)$ & $6.62^{*} \pm 0.31(+32.93)$ & $6.71^{*} \pm 0.34(+34.73)$ \\
\hline
\end{tabular}

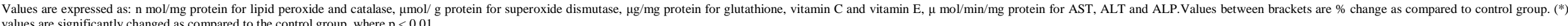

Table 5. Improvement perfentages of free radical scavangers and liver fuction enzymes after ummunization with different antigens

\begin{tabular}{|c|c|c|c|c|c|}
\hline Parameters & Saponin & Fasciola worm homogenates & $\begin{array}{l}\text { Fasciola worm } \\
\text { homogenates+ saponin }\end{array}$ & $\begin{array}{l}\text { Schistosoma } \\
\text { worm homogenates }\end{array}$ & $\begin{array}{l}\text { Schistosoma worm homogenates+ } \\
\text { saponin }\end{array}$ \\
\hline Lipid peroxide & 26.66 & 23.33 & 13.33 & 13.00 & 6.66 \\
\hline Glutathione & 34.76 & 24.93 & 17.01 & 19.40 & 11.28 \\
\hline Vitamin C & 36.57 & 28.85 & 14.57 & 20.00 & 11.42 \\
\hline Vitamin E & 32.39 & 25.61 & 20.63 & 25.33 & 14.21 \\
\hline Catalase & 22.83 & 17.47 & 10.61 & 20.26 & 16.28 \\
\hline Superoxide dismutase & 22.61 & 13.54 & 9.14 & 9.57 & 7.13 \\
\hline $\begin{array}{c}\text { Aspartate } \\
\text { aminotransferase }\end{array}$ & 36.58 & 30.31 & 22.17 & 24.25 & 17.71 \\
\hline $\begin{array}{c}\text { Alanine } \\
\text { aminotransferase }\end{array}$ & 33.39 & 22.50 & 18.48 & 20.42 & 15.48 \\
\hline Alkaline phosphatase & 41.96 & 35.34 & 32.93 & 25.10 & 23.29 \\
\hline
\end{tabular}


Table 6. Number of worm burden, relative sex ratio and reduction percent of worms in female mice liver vaccinated with Fasciola and Schistosoma worm, saponin and its mixed antigens.

\begin{tabular}{|c|c|c|c|c|c|c|c|}
\hline \multirow{2}{*}{ Groups } & Total & Male & Female & $\% \mathrm{R}$ & $\% \mathrm{R}$ & $\% \mathrm{R}$ & RSR \\
\cline { 2 - 8 } & $(\mathrm{T})$ & $(\mathrm{M})$ & $(\mathrm{F})$ & $\mathrm{T}$ & $\mathrm{M}$ & $\mathrm{F}$ & \\
\hline Infected & $44.00 \pm 5.87$ & $24.00 \pm 3.00$ & $20 \pm 3.00$ & - & - & - & 1 \\
\hline Saponin & $6.00^{*} \pm 1.35$ & $4.00^{*} \pm 1.00$ & $2.00^{*} \pm 2.00$ & 86.36 & 83.33 & 90.00 & 1.66 \\
\hline Shcistosoma & $14.00^{*} \pm 2.00$ & $8.00^{*} \pm 0.50$ & $6.00^{*} \pm 1.00$ & 68.11 & 66.66 & 70.00 & 1.11 \\
\hline Schistosoma + Saponin & $15.00^{*} \pm 2.00$ & $9.00^{*} \pm 1.47$ & $6.00^{*} \pm 0.86$ & 62.50 & 70.00 & 75.00 & 1.25 \\
\hline Fasciola & $11.00^{*} \pm 3.67$ & $7.00^{*} \pm 2.00$ & $4.00^{*} \pm 1.00$ & 75.00 & 70.83 & 80.00 & 1.45 \\
\hline Fasciola + Saponin & $24.00^{*} \pm 3.26$ & $11.00^{*} \pm 2.00$ & $13.00^{*} \pm 2.00$ & 45.45 & 54.16 & 35.00 & 0.70 \\
\hline
\end{tabular}

Data are mean SD of five mice in each group.

RSR is the relative sex ratio between male and female worms in treated groups as compared to infected group.

Maghraby et al. [14] who found the same results and attributed this effect to the separated bands observed during the electrophoretic analysis of saponin, Fasciola worm homogenate, and their mixed antigen. Electrophoresis revealed the presence of 9 bands for saponin, 8 bands for Fasciola worm antigen, and 7 bands only for the mixed antigen. There were two common bands (shared antigens at 102 and $110 \mathrm{kDa}$ ) between Fasciola worm antigen and saponin. One common band was observed between Fasciola worm homogenate and Fasciola worm homogenate following immunization with saponin at $102 \mathrm{kDa}$. Hence the high level of saponin protection may arise from the presence of two shared antigens and the diminution of the protective immunity of the antigen followed by immunization with saponin may be due to the presence of one common antigen.

In the present study, Schistosoma and Fasciola worm homogenate in combination with or without saponin has an immunostimulatory effect by increasing the level of $\operatorname{IgM}$ and $\mathrm{IgG}$ against CAP, SWAP and SEA. This is in accordance with de Oliveira et al. [31], who showed higher levels of IgG antibodies in patients with acute compared with chronic schistosomiasis. In addition, Maghraby et al. [14] recorded an elevation of $\operatorname{IgG}$ and $\operatorname{IgM}$ in immunized mice with $F$. gigantica worm antigen and post challenged with $S$. mansoni cercariae.

The host's response to $S$. mansoni infection involved the production of reactive oxygen species where the antioxidant enzymes represented a target for immune elimination of adult worms [32]. The present data revealed a significant increase in lipid peroxide and superoxide dismutase, while there was a significant decrease in the other parameters. These results indicate that infection with $S$. mansoni impairs the antioxidant system since the level of glutathione depletion is used as an index of oxidative stress and is a sign that hepatic cells are utilizing more antioxidant defenses [33]. This is in accordance with
$\% \mathrm{R}$ is percentages of reduction of total $(\mathrm{T})$, male $(\mathrm{M})$ and female $(\mathrm{F})$ worm numbers. $*)$ values are significantly change as compared to infected group, where $\mathrm{p}<0.01$

Hamed [34] who found that the glutathione level was decreased after parasitic infection. Gharib et al. [35] attributed the decreased level of glutathione to the increased cytoxicity with $\mathrm{H} 2 \mathrm{O} 2$ which is produced as a result of inhibition of glutathione reductase that keeps glutathione in its reduced form. Pascal et al. [36] and Soliman et al. [37] reported that oxidative stress due to schistosomiasis causes an elevation in lipid peroxide, since the complex mechanism of lipid peroxidation is known to require the participation of highly reactive oxygen and other reactive oxygen metabolites in the chain of biochemical reactions; thus whenever these free radicals are involved, lipid peroxides are in turn increased. Hence lipid peroxide serves as a marker of cellular oxidative stress and has long been recognized as a major consecutive factor of oxidative damage in chronic diseases [8].

With regard to vitamin $\mathrm{C}$ and coinciding with the present results, Frei et al. [38] reported that peroxyl radicals are trapped by ascorbate and thus the level of the enzyme and vitamin decreased during the free radical scavenging process. Also, the reduction of vitamin $\mathrm{E}$ after schistosomal infection occurs since the vitamin acts as a soluble antioxidant to protect biological membranes against oxidative stress which leads to maintenance of cell function. Moreover, Sokal et al. [39] reported that vitamin E protects hepatocytes against lipid peroxidation and toxic injury.

In Schistosomal infection, peroxide dismutation yields $\mathrm{H} 2 \mathrm{O} 2$, which is detoxified by catalase and thus results in a decline in its activity $[39,40]$. Superoxide dismutase detoxifies the cytotoxic $\mathrm{O} 2$ and is thus generally considered a potent antioxidant [41]. The present data revealed a significant increase in SOD after $S$. mansoni infection in mice, which was confirmed by Shaheen et al. [42] who found the same results and attributed this increase to an increase in peroxidative stress in the liver. Son et al. [8] attributed the increase in SOD to the enhancement of 
its mRNA expression as a result of exposure to superoxide and hydroxil radicals. Vaccination with different antigens improved the level of antioxidants due to the reduction of schistosomal toxins elaborated by the worm. This observation was confirmed through the observed reduction in the total worm burden as a result of vaccination with Fasciola or Schistosoma worm either alone or in combination with saponin.

Son et al. [8] attributed the enhancement of antioxidant levels after treatment with steroidal saponin that acted as a signal on gene expression of the antioxidant system, where SOD and catalse were slightly induced while glutathione was highly induced. This modified balance between the antioxidative enzymes might be able to remove superoxides efficiently.

Regarding AST, ALT and ALP enzyme activities and in accordance with our results, Hamed and Hetta [43] revealed a significant decrease in AST and ALT, while ALP recorded a significant increase after $S$. mansoni infection. They attributed these changes to the elaboration of free radicals due to schistosomal infection, which may cause damage to the mitochondrial membrane as well as an increase in cell membrane permeability that may lead to the discharge of its enzyme content.

Immunization with different antigens recorded improvement in AST, ALT and ALP enzyme activities. This is in accordance with Hamed [34], who recorded that vaccination with the excretorysecretory antigen of Fasciola hepatica worm enhanced the level of liver function enzymes in mice. The author attributed this improvement to the reduction in schistosomal toxins as a result of diminution of total worms after vaccination. In the present study, saponin recorded the most potent effect than any other vaccines for inducing improvement. This is in accordance with Lee et al. [44] and Saeed et al. [45], who postulated the hepatoprotective action of saponin is mediated by enhancing the level of liver enzymes, enhancing the enzymes responsible for antioxidant activity; scavenging free radicals responsible for cell damage and induction of regeneration of the liver cells.

Confirming our results through the antischistosomal, Haçariz et al. [12] stated that Quil A, the purified form of saponin, has protective elements that are useful in combating liver fluke infections with the observed higher antibody isotype activity, particularly for $\operatorname{IgA}$, and Th1 proliferation, which may indicate some of the mechanisms leading to reduced fluke fecundity.

The histopathological observation of the liver sections gives additional support to the efficacy of these antigens' protection against schistosomiasis. Infected liver revealed an increased number and size of granulomata, live miracidia, extensive fibrous tissue accumulation, widening of the portal tracts as angiomatoid reaction, and extensive bile duct proliferation. Our results are in accordance with those of Ali and Hamed [46] and Hamed [34] who found the same histopathological architecture of the liver after challenge.

Infected mice vaccinated with different antigens showed abatement of schistosomal activity, diminution in number and size of granulomata, evidence of increased immune reaction manifested by a lymphocytic cuff surrounding the granuloma, diminution of its fibrotic and collagen content, and destruction of Schistosoma ova. In accordance with these finding, Hamed [39] observed more or less the same pathological features in $S$. mansoni infected mice liver vaccinated with the excretory- secretory product of Fasciola hepatica worm.

In conclusion, Fasciola or Schistosoma worm antigens mixed with or without saponin as well as saponin alone succeeded to protect mice against $S$. mansoni infection with more potent effect than the separate saponin and Fasciola antigens. This protection is achieved by reduction in the total of male and female worms as well as in the levels of toxins elaborated by them, which confirms the role of these antigens in eliminating the product of oxidative stress and assistance in immune-mediated destruction of eggs that ameliorate the histopathological picture of the liver cells and preserve its function. Further work will be required to pinpoint the precise mechanisms involved in the adjuvant effect observed.

\section{Acknowledgements}

The authors would like to thank Assistant Professor Dr. Kamel H. Shaker, Natural Products Chemistry Department, National Research Center (Cairo, Egypt), University of Bayreuth Organic Chemistry, NW11, 1/2, D- Bayreuth, Germany, for supplying the extract of saponin. The authors also would like to thank Assistant Professor Dr. Mahmoud el-Sherbiney who kindly offered Fasciola worm homogenates.

\section{References}

1. Kojima S (2004) Overview: From the horse experimentation by Prof. Akira Fujinami to paramyosin. Parasitol. Internat. 53: 151-162. 
2. McManus DP and Loukas A (2008) Current status of vaccines for schistosomiasis. Clin Microbiol Rev 21: 22542.

3. Hillyer GV (1985) Induction of immunity in mice to Fasciola hepatica with Fasciola/Schistosoma cross-reactive defined immunity antigen. Am J Trop Med Hyg 34: 1127131.

4. Hillyer GV (1976) Can we vaccinate against schistosomiasis? Feder Proceed 35: 2568- 571.

5. Moharram FA and El-Shenawy SM (2007) Antinociceptive and anti-inflammatory steroidal saponins from Dracaena ombet. Planta Medica 73: 1101-106.

6. Bachran C, Sutherland M, Heisler I, Hebestreit P, Melzig MF (2006) The saponin-mediated enhanced uptake of targeted saporin-based drugs is strongly dependent on the saponin structure. Exp Biol Med 231: 412-420.

7. Witthawaskul P, Panthong A, Kanjanapothi D, Taesothikul T, Lertprasertsuke N (2003) Acute and subacute toxicities of the saponin mixture isolated from Schefflera leucantha Viguier. J Ethnopharmacol 89: 115-121.

8. Son IS, Kim JH, Sohn HY, Son KH, Kim JS, Kwon CS (2007) Antioxidative and hypolipidemic effects of diosgenin, a steroidal saponin of yam (Dioscorea spp.), on high-cholesterol fed rats. Bioscience Biotech Biochem 71: 3063-071.

9. Tian F, Zhang X, Tong Y, Yi Y, Zhang S, Li L, Sun P, Lin L, Ding JPE (2005) A new sulfated saponin from sea cucumber, exhibits anti-angiogenic and anti-tumor activities in vitro and in vivo. Cancer Biol Therapy 4: 874-882.

10. Skene CD and Sutton P (2006) Saponin-adjuvanted particulate vaccines for clinical use. Methods 40: 53-59.

11. de Sousa CBP, Santos WR, Casas CP, de Souza EP, Tinoco LW, Eberl M, Langermans JAM, Frost PA, Vervenne RA, Dam GJV, Deelder AM, Thomas AW, Coulson OS, Wilson A (2001) Cellular and humoral immune responses and protection against schistosomes induced by a radiation-attenuated vaccine in chimpanzees. Infect Immunity 69: 5352-362.

12. Haçarız O, Sayers $G$, McCullough, M, Garrett $M$, O'Donovan J, Mulcahy G (2009) The effect of Quil A adjuvant on the course of experimental Fasciola hepatica infection in sheep. Vaccine 27: 45-50.

13. Marston A, Wolfender JL, Hostettmann K (2000) Analysis and isolation of saponins from plant material. In: Saponins in Food, Foodstuffs and Medicinal Plants. Annual Proceedings of the Phytochemical Society (W Oleszek and A Marston, editors), Clarendon Press, Oxford and London. pp.1-12.

14. Maghraby AS, Shker KH, Zahran HG, El-Sherbiny M (2007) In vivo, the immunological effects of Fasciola gigantica worms homogenate mixed with saponin on mice infected with Schistosoma mansoni. J Med Sci 7: 724-731.

15. Bradford MM (1976) A rapid and sensitive method for the quantitation of microgram quantities of protein utilizing the principle of protein-dye binding. Anal Biochem 72: 248254.

16. Oliver L and Stirewalt MA (1952) An efficient method for the exposure of mice to cercariae of Schistosoma mansoni. J Parasitol 39: 19-23.

17. Hillyer GV, Pelley RP, de Diaz AD (1979) Solubilization of antigens of Fasciola hepatica which react with antibodies to Schistosoma mansoni. J Parasitol 65: 55-60.

18. Buege JA and Aust SD (1978) Microsomal lipid peroxidation. Meth Enzymol 52: 302-310.
19. Jogata SK and Dani HM (1982) A new colorimetric technique for the estimation of vitamin C (using Folin Phenol Reagent). Anal Biochem 127: 178-182.

20. Angustin J, Klevn BP, Barker JB, Venagepa PB (1985) Vitamin E. In: Methods of Vitamin Assay. 4th Edition, Academic Press, Inc., NY pp. 266-267.

21. Nelson DP and Kiesow LA (1972) Enthalpy of decomposition of hydrogen peroxide by catalase at 25 (with molar extinction coefficients of $\mathrm{H}_{2} \mathrm{O}_{2}$ solution in the (U.V.). Anal Biochem 49: 474-478.

22. Nishikimi M, Rae NA, Yagi K (1972) The occurrence of superoxide anion in the action of reduced phenazine methosulphate and molecular oxygen. Biochem Biophy Research Communication 46: 849-853.

23. Reitman S and Frankel S (1957) Colorimetric method for the determination of serum glutamic oxaloacetic and glutamic pyruvic transaminases. Am J Clin Pathol 28: 56-63.

24. Kind PR and King EJ (1954) Estimation of plasma phosphatase by determination of hydrolysed phenol with amino - antipyrine. J Clin Pathol 7: 322-326.

25. Smithers RS and Terry RJ (1965) The infection of laboratory hosts with cercariea of Schistosoma mansoni and the recovery of worm. Parasitology 55: 695-700.

26. Tendler M, Pinto RM, Oliveira LA, Gebara G, Katz N (1968) Schistosoma mansoni vaccination with adult worm antigens. Inter J Parasitol 16: 347 -352.

27. Fallon PG, Smith P, Nicholls T, Modha J, Doenhoff MJ (1994) Praziquantel induced exposure of Schistosoma mansoni alkaline phosphatase drug-antibody synergy, which acts preferentially against female worm. Parasitology16: 529-535.

28. Hiraishi H, Terano A, Sugimoto T, Harada T, Razand M, Ivey KJ (1994) Protective role of intracellular superoxide dismutase against extracellular oxidants in cultured rat gastric cells. J Clin Investig 93: 331-338.

29. Ronald T, Chapman S, Hall L (1983) Statistics in Research Development. Bungay, Suffolk, N.Y. and London: The Chaucer Press Ltd. pp.264-300.

30. Bergquist NR, Leonardo LR, Mitchell GF (2005) Vaccinelinked chemotherapy: can schistosomiasis control benefit from an integrated approach? Trend Parasitol 21: 112-117.

31. de Oliveira EJ, Kanamura HY, Takei K, Hirata RD, Valli LC, Nguyen NY, de Carvalho Rodrigues I, de Jesus AR, Hirata MH (2008) Synthetic peptides as an antigenic base in an ELISA for laboratory diagnosis of Schistosomiasis mansoni. Trans Roy Soc Trop Med Hyg 102: 360-366.

32. Loverde PT (1998) Do antioxidants play a role in schistosome host-parasite interactions? Parasitol Today 14: 284-289.

33. Ip S, Yiu HY, Kos KM (2000) Differential effect of schisandrin B and dimethyl diphenyl bicarboxylate (DDB) on hepatic mitochondrial glutathione redox status in carbon tetrachloride intoxicated mice. Mol Cell Biochem 205: 111114.

34. Hamed MA (2006) Excretort- secretory product of Fasciola hepatica worm protects against Schistosoma mansoni infection in mice. Ind J Exp Biol 44: 554-561.

35. Gharib B, Abd-Allah OM, Dessein H, De-Reggi M (1999) Development of eosinophil peroxidase activity and concomitant alteration of antioxidant defenses in the liver of mice infected with Schistosoma mansoni. J Hepatol 30: 594602.

36. Pascal M, Abd-Allah OM, El-Wali NE, Mergani A, Qurashi MA, Magzoub M, De-Reggi M, Gharib B (2000) 
Hyaluronate levels and markers of oxidative stress in the serum Sudanese subjects at risk of infection with Schistosoma mansoni, Trans Roy Soc Med Hyg 94: 66-70.

37. Soliman KM, El-Ansary AK, Mohamed AM (2000) Effect of carnosine administration on certain metabolic parameters in bilharzial infected hamsters. J Egypt Soc Parasitol 30: 455-468.

38. Frei, B, Stocker, R, Ames, BN (1988) Antioxidant defenses and lipid peroxidation in human blood plasma. Proceed Nat Acad Sci 88: 9748-9752.

39. Sokal RJ, McKim JM, Goff MC, Ruyle SZ, Devereaux MW, Han D, Packer L, Everson G (1998) Vitamin E reduces oxidant injury to mitochondria and hepatotoxicity of taurochenodeoxycholic acid in rat. Gastroenterology 114: 164-174.

40. Hahn UK, Bender RC, Bayne CJ (2001) Killing of Schistosoma mansoni sperocytes by hemocytes from resistant Biomphalaria glabrata: role of reactive oxygen species. J Parasitol 87: 292-299.

41. Hirsch C, Zouain CS, Alves JB, Goes AM (1997) Induction of protective immunity and modulation of granulaomatous hypersensitivity in mice using PIII, an anionic fraction of Schistosoma mansoni adult worm. Parasitology 115: 21-28.

42. Shaheen AA, Abd-El- Fattah AA, Ebeid FA (1994) Effects of praziquantel treatment on lipid peroxid levels and superoxide dismutase activity in tissues of healthy and Schistosoma mansoni infected mice. Arzneimittel Forschung 44: 94-96.
43. Hamed MA and Hetta MH (2006). Efficacy of Citrus reticulata and Mirazid in treatment of Schistosoma mansoni. Memorias do Instituto Oswaldo cruz 100: 771-778.

44. Lee HU, Bae EA, Han MJ, Kim DH (2005) Hepatoprotective effect of 20(S)- ginsenosides Rg3 and its metabolite 20 (S)-ginsenoside $\mathrm{Rh} 2$ on tert-butyl hydroperoxide-induced liver injury. Biol Pharma Bulletin 28: 1992-1994.

45. Saeed MK, Deng Y, Dai R (2008) Attenuation of Biochemical Parameters in Streptozotocin-induced Diabetic Rats by Oral Administration of Extracts and Fractions of Cephalotaxus sinensis. J Clin Biochem Nutrit 42: 21-28.

46. Ali SA and Hamed MA (2006) Effect of Ailanthus altissima and Zizyphus spina Christi on bilharzial infestation in mice: histological and histopathological Studies. J App Sci 6:1437-1446.

\section{Corresponding author}

Prof. Dr. Amany Sayed Maghraby

Therapeutic Chemistry Department

Laboratory of Immunology and Infectious Diseases

Center of Excellence for Advanced Sciences

National Research Center

Dokki, Cairo, Egypt

National Research Center, Tahrir St., Dokki, Cairo, Egypt

Email: maghraby_amany@yahoo.com

Conflict of interests: No conflict of interests is declared. 